\title{
Toponymic Data Helps to Reveal the Occurrence of Previously Un- known Populations of Wild Zamia pumila L. on Volcanic Substrates in South Central Puerto Rico
}

\author{
Jaime R. Pagán-Jiménez ${ }^{1^{*}}$ and Julio C. Lazcano-Lara² \\ Author address: ${ }^{1}$ Faculty of Archaeology, Leiden University (The Netherlands), and Programa de Maestría en Arqueología, \\ Centro de Estudios Avanzados de Puerto Rico y el Caribe (Puerto Rico). ${ }^{2}$ Laboratory for Integrative Biology, Departamento \\ de Biología, Universidad de Puerto Rico, Río Piedras (Puerto Rico). \\ *Corresponding author: jpaganpr@yahoo.com
}

Received: February 26, 2013

Volume: 4:52-58

Published: April 30, 2013

(C) 2013 Society of Ethnobiology

\begin{abstract}
This is the first report of the occurrence of wild Zamia pumila L. Zamiaceae populations on various volcanic substrates in the piedmont area of south central Puerto Rico. Data acquisition and its field confirmation were possible after the identification of toponymic names in old and current maps, and historic documents of the island in which one of the indigenous names for the genus (marunguey [marungüey] or marungueyes) has been used for naming some localities. These preliminary data have deep implications for paleo- and neoethnobotanical research, and for population ecology of the species in Puerto Rico, because they expand the traditionally accepted range for the species on the island. Zamia has been described as one of the main food plants among pre-and post-Columbian inhabitants in two islands of the Greater Antilles, Hispaniola and Puerto Rico, where the most sophisticated pre-Columbian society of the Antilles, the Taínos, emerged. Our findings suggest that Zamia might have been more available to humans, as a food source, than previously thought.
\end{abstract}

Keywords: Zamia pumila, volcanic geology, Puerto Rico, ecology, biology, paleoethnobotany.

Introduction

Zamia L. Zamiaceae is the cycad genus with the widest distribution in the Neotropics. Its species are found from Florida to Bolivia (Norstog and Nicholls 1997). In the Antilles, it is represented by the Zamia pumila complex, a distinct, and monophyletic group (Caputo et al. 2004; Norstog and Nicholls 1997), with an undetermined number of species, ranging from 1 to 9 depending on the preferred taxonomic approach (e.g., Eckenwalder 1980; González-Géigel 2003; Meerow et al. 2007; Meerow et al. 2012; Stevenson 1987).

At present, populations of this species complex are known in Cuba, Hispaniola (Haiti and the Dominican Republic), Jamaica, Puerto Rico, the Bahamas, and the Cayman Islands, but there is no record of its native distribution throughout the Lesser Antilles (Stevenson et al. 2003). Although the genus is commonly associated with volcanic and limestone formations in the tropical American continent (Whitelock 2002), the only known and clear occurrence of the genus in volcanic formations across the
Antilles has been registered for Cuba (González-Géigel 2003).

In Puerto Rico, three Zamia species have been recognized (Acevedo and Strong 2005; Axelrod 2011; Meerow et al. 2012). Zamia erosa Cook and Collins Zamiaceae is widely distributed across the northern limestone region, where its abundance ranges from rare to locally dominant. The other two species $(Z$. pumila and Z. portoricensis Urb Zamiaccae) are distributed along interrupted, metamorphosed limestone (marble), and serpentine areas of south-central and southwestern Puerto Rico. They are geographically separated from $Z$. erosa by the metamorphic volcanic rock of the Cordillera Central (Figure 1).

During the last 8 years, archaeological findings in Puerto Rico (including Vieques island), Dominican Republic, Cuba, Saba, Trinidad and Aruba have consistently revealed the importance of Zamia for the pre-Columbian inhabitants of these islands (Mickleburgh and Pagán-Jiménez 2012; PagánJiménez 2007, 2009, 2011, 2013). Microbotanical residues, such as starch grains from subterranean 


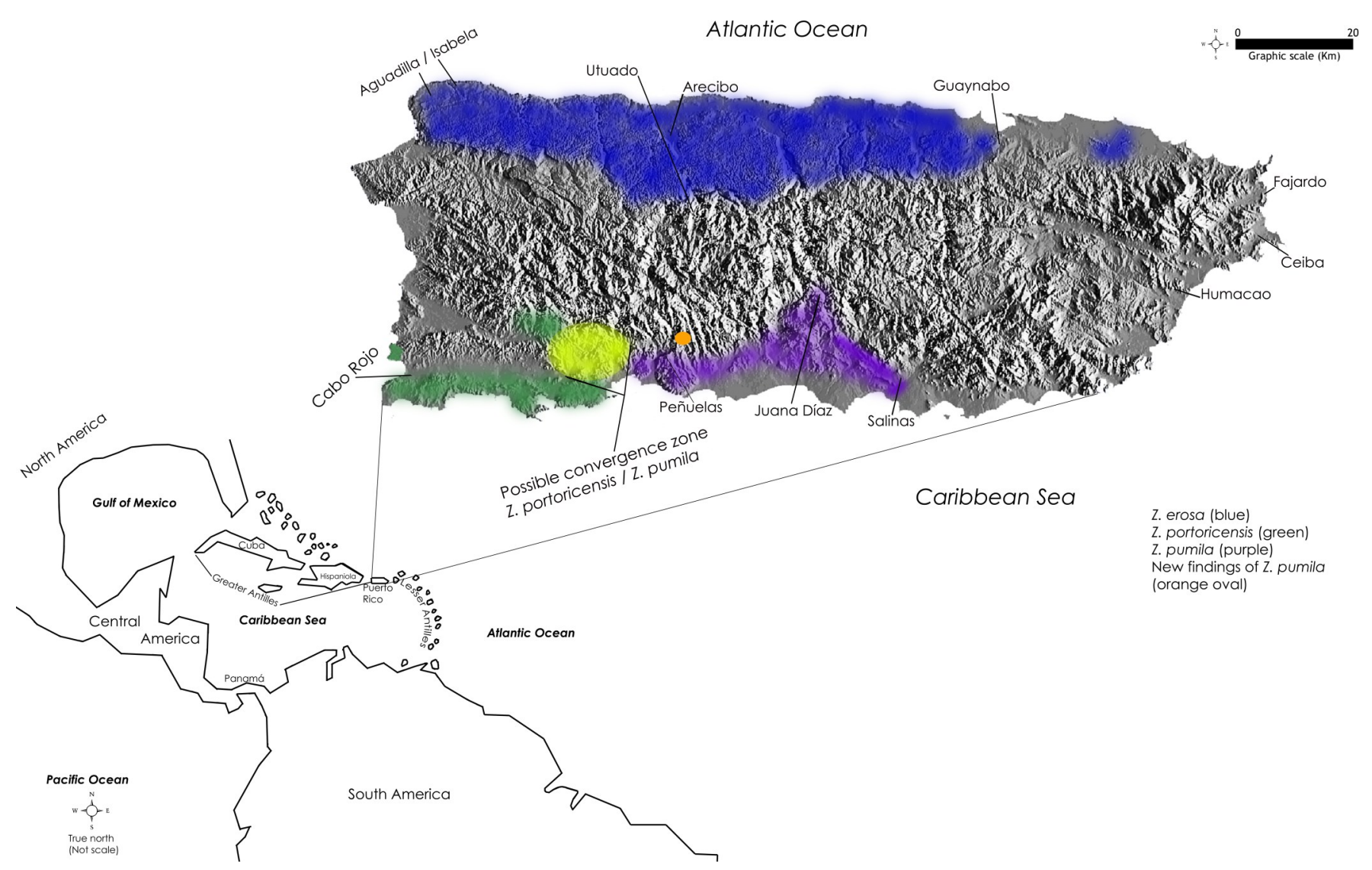

Figure 1. Potential distribution of the three wild Zamia species known for Puerto Rico according to herbarium collections, published literature, personal field surveys, and geologic substrates traditionally associated with them. Orange dot (or oval) is the general location of the populations in this report.

stems of Zamia, have been identified in a diverse array of food processing/cooking tools and in human dental calculus chronologically placed between c. 5000 to $450 \mathrm{BP}$. The use of the subterranean stems of Zamia as a starchy food source has also been documented for colonial times in islands such as Puerto Rico, Hispaniola and Cuba, where some detailed descriptions were offered mainly on its exploitation and processing for making foodstuffs (Abbad y Lasierra 2002; Las Casas 1909; Pagán-Jiménez 2007). Within this context it is difficult to explain archaeological remains of Zamia discovered outside the current distribution range of the genus on the Caribbean Islands and, above all, the presence of populations of this species complex growing on soils that do not have limestone/serpentine substrates.

The recovery of pre-Columbian Zamia remains in archaeological excavations from the east coast of Puerto Rico (Ceiba and Humacao municipalities), Vieques, the Lesser Antilles (e.g., Saba and Guadeloupe), Trinidad, and Aruba is intriguing. Therefore, it seems that the past distribution of species of Zamia on these islands is poorly understood. The findings reported here suggest that, in the past, this genus could have been much more widely distributed and may have reached other islands and exploited a wider array of soils.

\section{Methods}

\section{Documentary search}

Toponymy is a type of linguistic inquiry used for studying and classifying the names of places in which any topographical, natural (floristic, faunal), or functional feature of the locality is used for assigning a particular name to a determined point in the geography. Initial results from the search of the Puerto Rico Amerindian word for Zamia (i.e., marunguey) in $19^{\text {th }}$ and $20^{\text {th }}$ Century maps of the island, documents and satellite images (Córdova1831; Erhard 1861, Google Earth 2012) have revealed its use for naming: (1) a secondary road between the southern municipalities of Ponce and Peñuelas (Camino los Marungueyes); (2) 


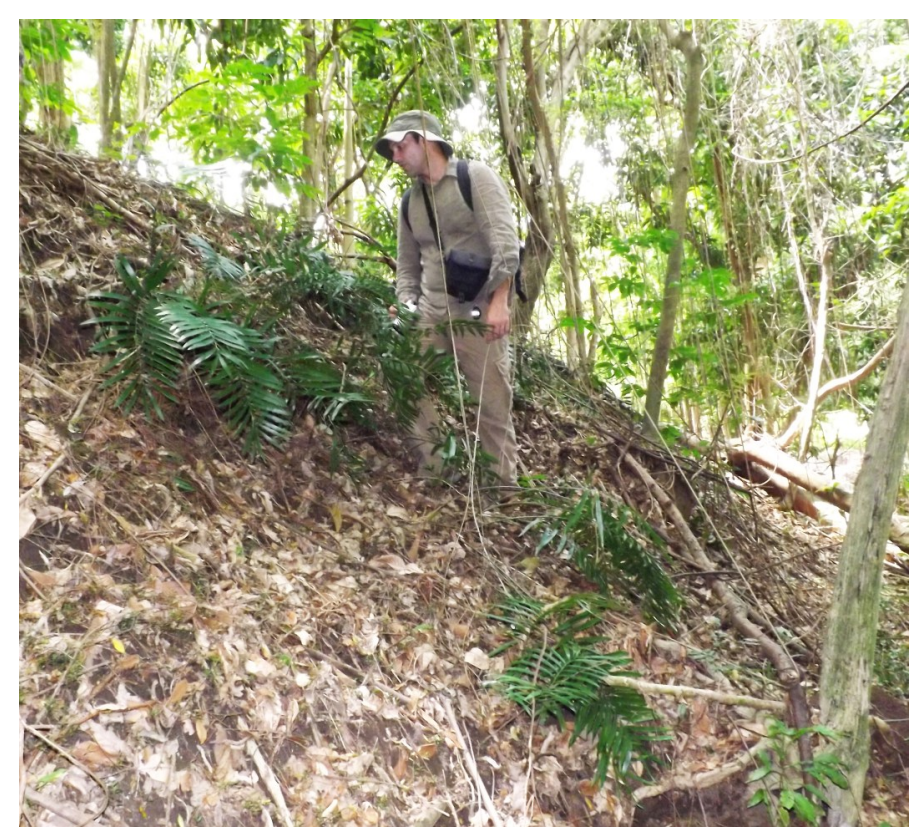

Figure 2. Habitat of Zamia pumila L. in P-2 (left) and P-3 (right).

a lagoon, a coastal point, and a creek in the eastern municipalities of Fajardo and Vieques island (Laguna Marungueyes, Punta Marunguey, Quebrada Marungueyes, respectively); and (3) another coastal point in the northern municipality of Arecibo (Punta de Marunguey). The locality in Arecibo is the only one situated on a limestone substrate, whereas the other sites are clearly found on various volcanic substrates where Zamia species have never been recorded or reported. This communication is focused in one of the areas found during the toponymic search: Camino los Marungueyes.

\section{Field survey}

Based on the geographical information, we conducted field studies to confirm if populations of Zamia occur at two different volcanic substrates in the periphery of Camino los Marungueyes (Figure 1, orange dot). We explored the vicinity of Camino Los Marungueyes, which is mostly a semi-deciduous secondary forest between Tallaboa Alta/Rucio and Quebrada Limón in the municipalities of Peñuelas and Ponce. We also interviewed local senior residents of the area who had general knowledge of the species and its uses, and obtained directions to locate two groups of plants.

\section{Results}

Three preliminary and localized field surveys have confirmed that small groups of Z. pumila grow wild near the vicinity of Camino Los Marungueyes (Figure

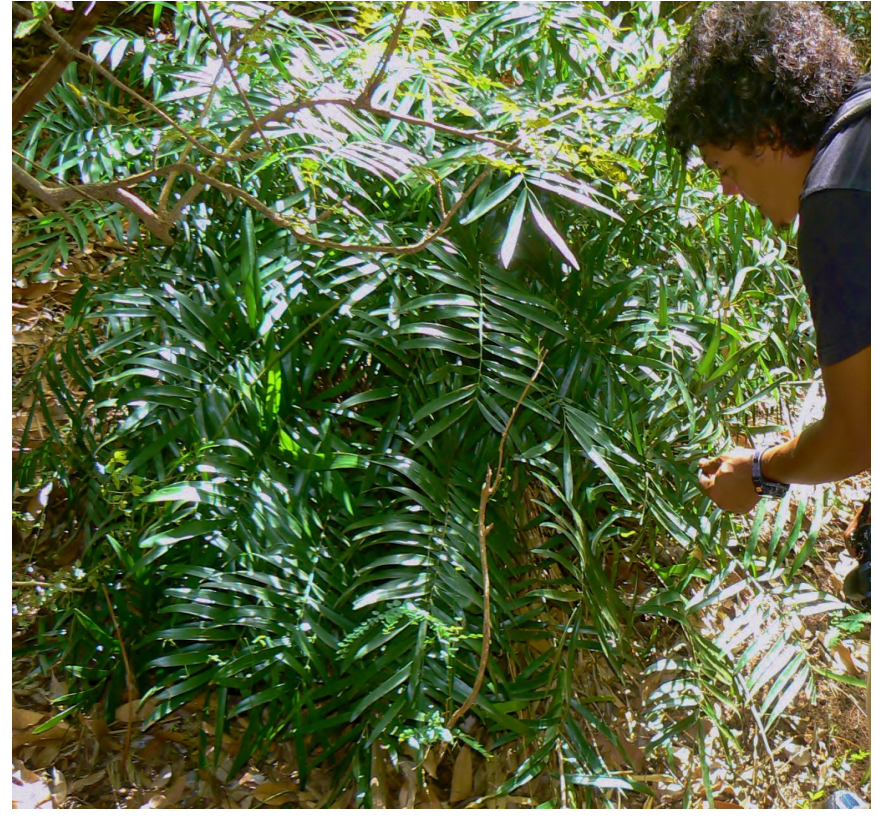

2). Intra-population data for the three $Z$. pumila groups described below (P-1 to P-3) are based on general observations obtained by a limited walkover in the area of interest. Two of the three groups found (P-1 and P-3) were located by using information provided by local senior residents of the area who have general knowledge of the species and of its past use as a foodstuff. P-2 was found during a general inspection of roadsides near Camino los Marungueyes.

The sites where plants of Zamia were found have mostly a volcanic substrate that belongs to the Yauco and Lago Grazas formations. The sites also have soils derived from augite andesite porphyry, augitehornblende porphyry and dacite (Krushensky 1998). It is worth mentioning that the Juana Díaz limestone formation is located $1.3 \mathrm{Km}$ farther south from these sites. The topography of the sites is highly irregular, comprising ridge tops surrounded by steep to moderate slopes. Soil types in the general area consist of well drained clay, silty clay and gravelly clay loam. Weathered and unweathered bedrock can be present at a depth of 10 to 36 inches (Web Soil Survey 2012).

One of the Z. pumila groups (P-1) lies on a c. $45^{\circ}$ slope in a secondary forest within the Yauco formation at an elevation of ca. 164 masl. This formation consists of siltstone, claystone, sandstone, limestone, and conglomerate (Krushensky 1998) and the soil surface in this specific location is a yellowish brown gravelly clay loam similar to the one described as 


\section{(f) Ethnobiolocy Letters
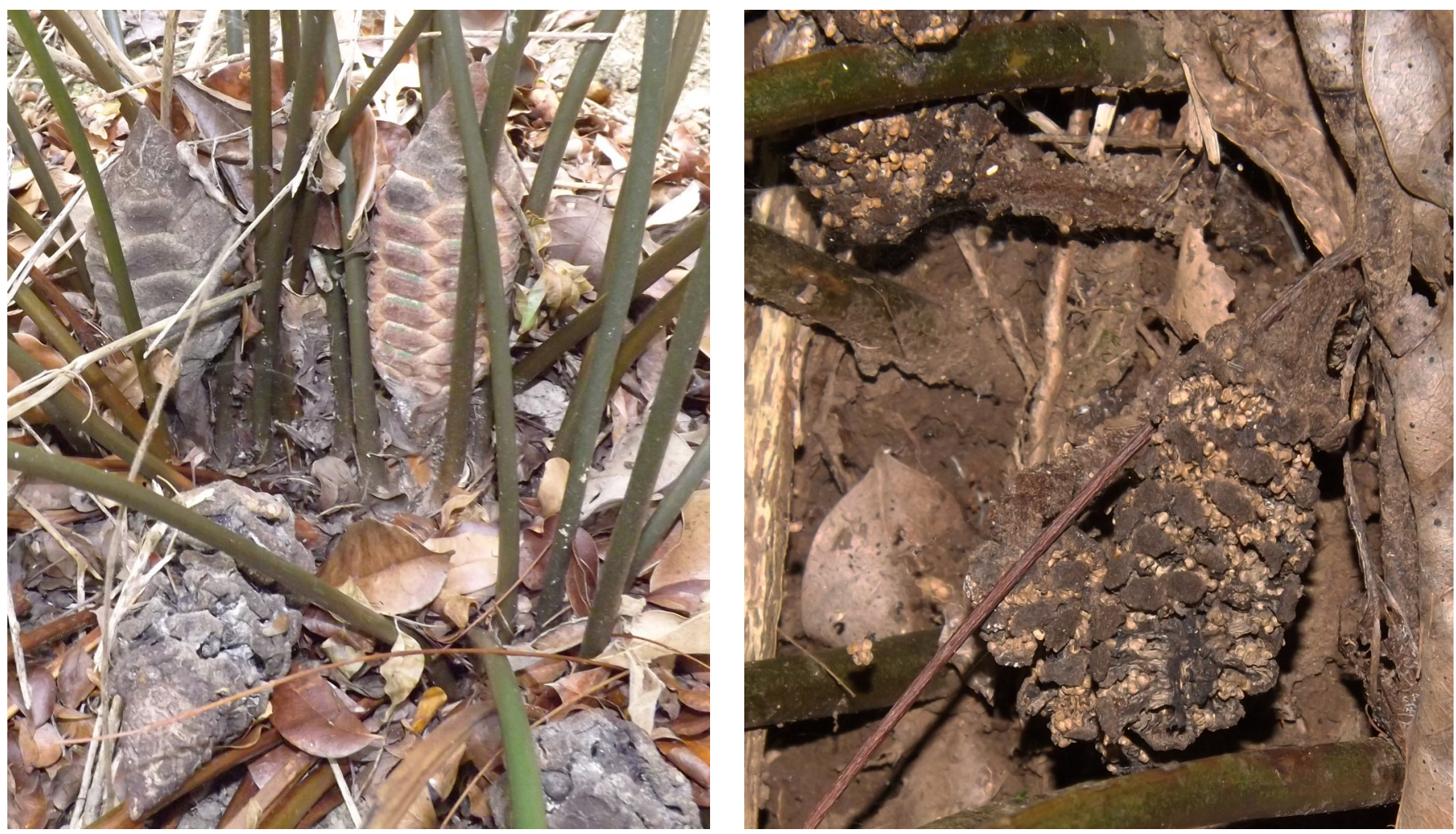

Figure 3. New and perished female (left) and male (right) cones as commonly seen in all the surveyed groups.

Caguabo gravelly clay loam (Web Soil Survey 2012). The other 2 groups (P-2 and P-3) grow on $30-70^{\circ}$ slopes in secondary forests near the vicinity of Camino los Marungueyes at an elevation between 180 to 220 masl (Figure 2). Both groups are located very close to two different ephemeral creeks and are approximately $1.2 \mathrm{Km}$ to the north of P-1. These 2 groups grow on the volcanic augite andesite porphyry substrate, which basically consists of dark gray groundmass together with minor phenocrysts and microchrystals (Kaye 1959). The topsoil in the areas of P-2 and P-3 is silty clay with some minor variations in color, ranging from dark grayish to yellowish brown as described for the Mucara silty clay (Web Soil Survey 2012). As noted above, the forests the 3 groups inhabit are similar. They are composed of mixtures of exotic and native plants such as mango (Mangifera indica L. Anacardiaceae), corozo palms (Acrocomia media O.F. Cook Arecaceae) and other woody species in which Zamia individuals grow in the understory.

Preliminary data from P-1 reveals that at least 10 individuals are distributed in two small clusters of four and 6 plants each, separated by c. $15 \mathrm{~m}$. Both, male $(n=4)$ and female $(n=5)$ plants are present in these clusters and sometimes male and female plants are distributed in pairs. Other mature plants were detected to the east of the visited area although they are distributed at higher points in the slope on private property and are generally separated by $10-20 \mathrm{~m}$ each.

Observations made for P-2 indicate that there are 5 to 6 individuals from both sexes. At least 3 of them of undetermined sex are clustered while the other 2 or 3 are separated from each other by 5 to $10 \mathrm{~m}$. One isolated individual of undetermined sex was found at the edge of a municipal road $40 \mathrm{~m}$. to the southeast of the main cluster. Males and females are not located close to each other. Nonetheless, a small cluster of young individuals was located below on the slope at no more than $3 \mathrm{~m}$ from one of the female plants.

General data acquired for P-3 establish a heavily scattered distribution pattern for Zamia individuals of both sexes. Two clusters comprise this group of Zamia. One of them is composed of only 2 individuals (at least 1 is a mature male plant) separated by c. 35 $\mathrm{m}$. The other cluster, located at more than $100 \mathrm{~m}$ to the north, consists of 4 individuals (at least 1 female and 1 male plant) separated from each other by approximately 25 to $65 \mathrm{~m}$. 
Although most of the plants were adults in all the surveyed groups (Figure 3), we did not find definitive evidence of recent sexual reproduction. The presence of decayed female cones with non-fecundated ovules suggests a lack of pollination during the previous reproductive season. Moreover the absence of seedlings around female plants implies that no recruitment has occurred in the recent past. Issues such as spatial separation of individuals of different sex, the local extinction of the pollinator, and poor recruitment may prevent successful sexual reproduction. This topic requires further investigation.

\section{Final remarks}

Our findings and general observations have shown the occurrence of various wild Z. pumila groups (or populations) in the vicinity of Camino los Marungueyes, a former volcanic area of south-central Puerto Rico. These groups are composed mainly of mature and old individuals who apparently are not reproducing sexually. Preliminary data obtained through informal interviews with older residents near the areas of these findings suggest that past agricultural activities were the main source of impact on this species, thus heavily affecting the population structure and its reproductive system. These new findings of Z. pumila probably reveal one of the last redoubts for this species growing wild in a volcanic area of Puerto Rico.

Our data have implications for paleoethnobotanical and archaeological research because they support previous archaeobotanical records of Zamia for preColumbian sites outside the current range of the species in Puerto Rico and other Antillean islands (Mickleburgh and Pagán-Jiménez 2012; PagánJiménez 2007, 2013). This suggests that Zamia could have been naturally distributed in "unexpected" areas beyond its present distribution range in Puerto Rico, thus making this plant potentially available for human use and consumption in the past. However, it is important to stress that pre-Columbian human impact on Zamia has not been properly evaluated in the Antilles; thus, an alternative hypothesis that preColumbian indigenous people might have served as dispersal agents for the species into new habitats cannot be ruled out (Mickleburgh and Pagán-Jiménez 2012). Knowing that Zamia has played an important role for the pre-Columbian human subsistence strategies in the Antilles (see Pagán-Jiménez 2013; Veloz Maggiolo 1992), it is important to obtain a more complete data set in order to understand the past and present status of this genus in Puerto Rico and the rest of the Antilles. Based on archaeological, paleoethnobotanical, and ethnohistoric information, Zamia sp. appears to be one of the few wild species in the Greater Antilles that was widely used by indigenous people, mainly as a food source. This same information also reveals that this species could have been one of the key staples for different pre- and post -Columbian periods and peoples of the region, so it is likely that the original inhabitants of the islands had well established management strategies, which directly involved Zamia for at least 5000 years in Puerto Rico and other Antillean islands (Pagán-Jiménez 2013).

Historical ecology brings an ideal framework for understanding long term human-plant interaction processes (sensu Balée 2006; Erickson 2008) that could help us gain refined information on the role pre -Columbian populations played in many aspects of Zamia biology and biogeography through time. Historical ecology derives from the understanding that rather than "adapt to" or be "limited by" the environment, humans created, transformed, and managed cultural or anthropogenic (human-made) landscapes that suited their purposes (Erickson 2008; see also Lansing and Cox 2011; Smith 2011). Wild plants such as Zamia sp., together with human agents through time, could be easily placed within this scenario in the Antilles considering our findings. We do not know to what extent the current status of Zamia, including its known and current distribution pattern, is the result of natural or cultural forces. We believe the only plausible way for acquiring specific knowledge on both sides of the problem is through the formulation of concerted and well-balanced research incorporating both the social and natural sciences. We think this brief research communication is a good example of how important the integration of various disciplines is for expanding our knowledge about our natural and human world.

\section{Acknowledgments}

We would like to thank Dr. Javier Francisco Ortega (Florida International University), as well as to two anonymous reviewers, for kindly making valuable comments to previous versions of this writing. Many thanks also to Dr. Franklin S. Axelrod and Dr. Jean E. Turnquist (Universidad de Puerto Rico-Río Piedras) for kindly correcting our Caribbean Spanglish.

\section{References Cited}

Abbad y Lasierra, F. I. 2002. Historia Geográfica, Civily 
Natural de la Isla de San Juan Bautista de Puerto Rico. Ediciones Doce Calles, Madrid.

Acevedo, P., and M. Strong. 2005. Zamiaceae. In Monocotyledons and Gymnosperms of Puerto Rico and the Virgin Islands, edited by P. Acevedo and M. Strong, pp. 14-17. Contributions from the United States National Herbarium, Volume 52: 1-415. Smithsonian Institution, Washington DC.

Axelrod, F. S. 2011. A Systematic Vademecum to the V ascular Plants of Puerto Rico. SIDA, Botanical Miscellany Number 34: 1-420. BRIT Press, Fort Worth.

Balée, W. 2006. The Research Program of Historical Ecology. Annual Review of Anthropology 35:1-24.

Caputo , P., S. Cozzolino, P. de Luca, A. Moretti and D. W. Stevenson. 2004. Molecular Phylogeny of Zamia (Zamiaceae). In Cycad Classification. Concepts and Recommendations, edited by T. Walters and R. Osborne, pp. 149-158. CABI Publishing, Oxford.

Córdova, P. T. 1831. Memorias Geográficas, Históricas, Económicas y Estadísticas de la Isla de Puerto Rico. Oficina del Gobierno a cargo de D. Valeriano de Sanmillán, Madrid.

Eckenwalder, J. E. 1980. Taxonomy of the West Indian Cycads. Journal of the Arnold Arboretum 61:701722.

Erhard, G. C. 1861. Carte de l' Ile de Saint Jean de Puerto-Rico. Bulletin de la Société de Geographie 5.

Erickson, C. L. 2008. Amazonia: The Historical Ecology of a Domesticated Landscape. In Handbook of South American Archaeology, edited by H. Silverman and W. H. Isbell, pp. 157-183. Springer, NY.

González-Géigel, L. 2003. Zamiaceae. In Flora de la República de Cuba. Fascículo 8(4). A.R. Ganter Verlag $\mathrm{KG}$, Liechtenstein.

Google Earth. 2012. Google Earth Version 6.1.0.5001. Server kh.google.com, Mountain View, CA.

Kaye, C. A. 1959. Coastal Geology of Puerto Rico. US Department of the Interior, Geological Survey Professional Paper 317, Washington DC.

Krushensky, R. D. 1998. Geologic Map of Puerto Rico with Correlation Chart and Map Unit Descriptions. In Geology, Geochemistry, Geophysics, Mineral Occurrences and Mineral Resource Assessment for the Commonwealth of Puerto Rico, edited by W. Bawiec. US
Geological Survey Open-File Report 98-38, http:// pubs.usgs.gov/of/1998/of98-38/.

Lansing, S., and M. P. Cox. 2011. The Domain of the Replicators. Current Anthropology 52(1):105-125.

Las Casas, B. de. 1909. Apologética Historia de las Indias. Nueva Biblioteca de Autores Españoles 13, Madrid.

Meerow, A. W., D. Stevenson, J. Moynihan and J. Francisco-Ortega. 2007. Unlocking the Coontie Conundrum: The Potential of Microsatellite DNA Studies in the Caribbean Zamia pumila Complex (Zamiaceae). Memories of the New York Botanical Garden 98: 484-518.

Meerow, A. W., J. Francisco-Ortega, M. Calonje, M. Patrick Griffith, T. Ayala-Silva, D. W. Stevenson and K. Nakamura. 2012. Zamia (Cycadales: Zamiaceae) on Puerto Rico: Asymmetric Genetic Differentiation and the Hypothesis of Multiple Introductions. American Journal of Botany 99(11):1828 -1839 .

Mickleburgh, H. and J. R. Pagán-Jiménez. 2012. New Insights Into the Consumption of Maize and Other Food Plants in the Pre-Columbian Caribbean from Starch Grains Trapped in Human Dental Calculus. Journal of Archaeological Science 39:2468-2478.

Norstog, K. and T. J. Nicholls. 1997. The Biology of the Cycads. Cornell University Press, Ithaca, NY.

Pagán-Jiménez, J. R. 2007. De Antiguos Pueblos y Culturas Botánicas en el Puerto Rico Indígena. Paris Monographs in American Archaeology 18/British Archaeological Reports International Series. Archaeopress, Oxford.

Pagán-Jiménez, J. R. 2009. Nuevas Perspectivas Sobre las Culturas Botánicas Precolombinas de Puerto Rico: Implicaciones del Estudio de almidones en Herramientas Líticas, Cerámicas y de Concha. Cuba Arqueológica II(2):7-23.

Pagán-Jiménez, J. R. 2011. Early Phyto-Cultural Processes in the Precolonial Antilles: A PanCaribbean Survey for an Ongoing Starch Grain Research. In Communities in Contact. Essays in Archaeology, Ethnohistory and Ethnography of the Amerindian Circum-Caribbean, edited by C. L. Hofman and A. van Duijvenbode, pp. 87-116. Sidestone Press, Leiden.

Pagán-Jiménez, J. R. 2013. Human-Plant Dynamics in the Precolonial Antilles: A Synthetic Update. In The 
Oxford Handbook of Caribbean Archaeology, edited by W. Keegan, C. L. Hofman and R. RodríguezRamos, pp. 391-406. Oxford University Press, NY.

Smith, B. D. 2011. General Patterns of Niche Construction and the Management of Wild Plant and Animal Resources by Small-Scale PreIndustrial Societies. Philosophical Transactions of the Royal Society Biological Sciences 366:836-848.

Stevenson, D. W. 1987. Again the West Indian Zamias. Fairchild Tropical Garden Bulletin 42(3):2327.

Stevenson, D. W., A. Vovides and J. Chemnick. 2003. Regional Overview: New World. In Cycads. Status Survey and Conservation Action Plan, edited by J. Donaldson, pp. 31-38. The World Conservation Union, Gland, Switzerland.

Veloz Maggiolo, M. 1992. Notas sobre la Zamia en la Prehistoria del Caribe. Revista de Arqueología Americana 6:125-138.

Web Soil Survey. 2012. Puerto Rico. Available at: http://websoilsurvey.nrcs.usda.gov/app/. Accessed on May 24, 2012.

Whitelock, L. M. 2002. The Cycads. Timber Press, Portland.

\section{Biosketches}

Jaime R. Pagán-Jiménez (Doctorate in Anthropology, Universidad Nacional Autónoma de México, 2005) is Adjunct Professor of Archaeology at the Centro de Estudios Avanzados de Puerto Rico y el Caribe, and Research Affiliate in Caribbean Archaeology (Paleoethnobotany) at Leiden University, The Netherlands. He is also a Research Fellow of the Secretaría Nacional de Educación Superior, Ciencia, Tecnología e Innovación (SENESCYT, Proyecto Prometeo) ascribed to the Instituto Nacional de Patrimonio Cultural, Ecuador, where he advises the development of a national research program in Paleoethnobotany. His current research examines the paleoethnobotany of the Caribbean islands, French Guiana, and Ecuador, as well as the socio-politics of archaeological praxis in the Caribbean and Latin America.

Julio C. Lazcano-Lara (Ph.D. candidate, Departamento de Biología, Universidad de Puerto Rico-Río Piedras) is currently in his fourth year at the Laboratory for Integrative Biology lead by Dr. James D. Ackerman. He is a member of the Cycad Specialist Group, SSC-IUCN. His research is focused on the reproductive biology of Puerto Rican zamias and how it influences species differentiation and their patterns of genetic diversity. 